\title{
Properties of Milk Protein Gels Formed by Phosphates
}

\author{
R. Mizuno* and J. A. Luceyt ${ }^{1}$ \\ ${ }^{*}$ Food Research and Development Laboratory, Morinaga Milk Industry Co. Ltd., 1-83, 5-Chome Higashihara, Zama, Kanagawa $228-8583$ Japan \\ †Department of Food Science, University of Wisconsin-Madison, 1605 Linden Drive, Madison 53706
}

\begin{abstract}
We investigated the properties of gels that were formed by adding emulsifying salts, such as tetrasodium pyrophosphate (TSPP), to reconstituted milk protein concentrate solution. The $\mathrm{pH}$ of a $51 \mathrm{~g} / \mathrm{L}$ milk protein concentrate solution was adjusted to 5.8 after adding TSPP. Milk protein concentrate solutions were placed in glass jars and allowed to stand at $25^{\circ} \mathrm{C}$ for $24 \mathrm{~h}$. Gels with the highest breaking force were formed when TSPP was added at a concentration of $6.7 \mathrm{mM}$, whereas no gel was formed when TSPP was added at concentrations of $\leq 2.9$ or $\geq 10.5 \mathrm{mM}$. Several other phosphate-based emulsifying salts were tested but for these emulsifying salts, gelation only occurred after several days or at greater gelation temperatures. No gelation was observed for trisodium citrate. Gelation induced by TSPP was dependent on $\mathrm{pH}$, and the breaking force of gel was greatest at $\mathrm{pH}$ 6.0. Furthermore, when the concentration of milk protein concentrate in solution was increased to $103 \mathrm{~g} / \mathrm{L}$, the breaking force of the gel increased, and a clearly defined network between caseins could be observed by using confocal scanning laser microscopy. These results suggest that TSPP-induced gelation occurs when the added TSPP acts with calcium as a cross-linking agent between dispersed caseins and when the balance between (a reduced) electrostatic repulsion and (enhanced) attractive (hydrophobic) interactions becomes suitable for aggregation and eventual gelation of casein molecules.
\end{abstract}

Key words: casein, emulsifying salt, gelation

\section{INTRODUCTION}

Citrates and phosphates are added as emulsifying salts in the manufacture of processed cheese. These salts are not true emulsifiers but they increase casein dispersion, increase the water-holding capacity of proteins in processed cheese, and improve the ability of caseins to emulsify fat (Berger et al., 1998; Fox et al.,

Received March 26, 2007.

Accepted June 20, 2007.

${ }^{1}$ Corresponding author: jalucey@facstaff.wisc.edu
2000), although the mechanism of this phenomenon caused by emulsifying salts has not been fully elucidated. The textural and functional properties of processed cheese are influenced not only by the quality of natural cheese as an ingredient, but also by the quantity and type of emulsifying salts. In general, processed cheese tends to be soft and melts more easily when manufactured using trisodium citrate (TSC) as an emulsifying salt, whereas processed cheese tends to be hard and resistant to heat when manufactured using sodium phosphates (Dairy Management Inc., 2004). However, orthophosphate, pyrophosphate, and polyphosphates do not have identical influences on the textural and functional properties of processed cheese, although they are all phosphate-based emulsifying salts (Gupta et al., 1984). Furthermore, mixtures of emulsifying salts are usually used in the manufacture of processed cheese. For these reasons, the processed cheese system becomes complicated, and the control of the textural and functional properties of finished processed cheese products manufactured using emulsifying salts still depends greatly on the experience of operators.

We have previously studied the influence of various emulsifying salts on milk proteins using a simple system consisting of reconstituted milk protein concentrate (MPC) solution (Mizuno and Lucey, 2005). During the study, we observed that gelation occurred in some of the MPC solutions to which emulsifying salts were added. It is suggested that this gelation may be caused by a specific interaction between certain salts and caseins (Mizuno and Lucey, 2005). It is also possible that a similar interaction could occur when this emulsifying salt, which includes gelation, is used during the manufacture of processed cheese, which could affect the textural and functional properties of cheese. There appear to be few studies on the ability of emulsifying salts to induce milk gelation in the absence of rennet or under very low $\mathrm{pH}$ values. The present study was performed to investigate emulsifying salts-induced gelation of milk and to study the effect of different types and concentrations of emulsifying salts, as well as other conditions such as $\mathrm{pH}$, salt, and total solids content on these gel properties. 


\section{MATERIALS AND METHODS}

\section{Materials}

Milk protein concentrate powder (Alapro 4560) was purchased from New Zealand Milk Products (Santa Rosa, CA). The protein, casein, ash, and calcium content of the MPC powder were 42.0,34.0, 6.0, and $2.5 \mathrm{~g} / 100$ $\mathrm{g}$, respectively. Trisodium citrate dihydrate (CAS No 68-04-2; $\mathrm{C}_{6} \mathrm{H}_{5} \mathrm{O}_{7} \mathrm{Na}_{3} \cdot 2 \mathrm{H}_{2} \mathrm{O}$ ) was purchased from SigmaAldrich (St. Louis, MO), and disodium phosphate (DSP) anhydrous (CAS No. 7558-79-4; $\mathrm{Na}_{2} \mathrm{HPO}_{4}$ ), tetrasodium pyrophosphate (TSPP) anhydrous (CAS No. 7722-88-5; $\mathrm{Na}_{4} \mathrm{P}_{2} \mathrm{O}_{7}$ ), sodium tripolyphosphate (STPP) anhydrous (CAS No. 7758-29-4; $\mathrm{Na}_{5} \mathrm{P}_{3} \mathrm{O}_{10}$ ), and sodium hexametaphosphate (SHMP) [CAS No. 68915-31-1; $\left.\mathrm{Na}\left({ }_{n+2}\right) \mathrm{P}_{\mathrm{n}} \mathrm{O}\left({ }_{3 n+1}\right)\right]$ were purchased from Astaris (St. Louis, MO). The mean degree of polymerization of SHMP was 5.6 when determined using the following method of Odagiri and Nickerson (1964). The $\mathrm{pH}$ of 0.5 $\mathrm{g}$ of SHMP in $450 \mathrm{~mL}$ was reduced to 2.5 by adding 1 $N \mathrm{HCl}$ and diluted to $500 \mathrm{~mL}$. A $200-\mathrm{mL}$ portion was immediately back-titrated with $0.1 \mathrm{~N} \mathrm{NaOH}$. The distance between the 2 equivalence points of the titration curve is equivalent to the weak acid function $\left(f_{w}\right)$. Another $200-\mathrm{mL}$ portion of the solution was refluxed to hydrolyze to the ortho form for $4 \mathrm{~h}$. Again, the solution was back-titrated with $0.1 \mathrm{~N} \mathrm{NaOH}$. In this case, the distance between the 2 equivalence points is equivalent to the strong acid function $\left(f_{s}\right)$. The number of phosphate atoms in a polyphosphate molecule (chain length), n, was calculated as follows:

$$
\begin{gathered}
\mathrm{n}=(\text { total phosphorus/number } \\
\text { of polyphosphate molecules })=2 f_{s} / f_{w} .
\end{gathered}
$$

\section{Sample Solution Preparation}

Milk protein concentrate solutions were prepared by dissolving MPC powder at a concentration of $51 \mathrm{~g} / \mathrm{L}$ or $103 \mathrm{~g} / \mathrm{L}$ in milli-Q water (Millipore, Billerica, MA) and hydrated by heating at $50^{\circ} \mathrm{C}$ for $30 \mathrm{~min}$. After cooling to $25^{\circ} \mathrm{C}$, sodium azide was added to the solution at a concentration of $0.2 \mathrm{~g} / \mathrm{L}$ to inhibit bacterial growth. Then, TSC, DSP, TSPP, STPP, or SHMP was added to the MPC solution, and the $\mathrm{pH}$ was adjusted to the desired $\mathrm{pH}$ value with $1 \mathrm{~N} \mathrm{HCl}$ or $1 \mathrm{~N} \mathrm{NaOH}$. Solutions were prepared with $\mathrm{pH}$ values ranging from 5.4 to 7.0. In some samples, calcium (0 to $100 \mathrm{mM}$ ) in the form of calcium chloride dihydrate or $\mathrm{NaCl}(0$ to $85.5 \mathrm{mM}$ ) was also added before $\mathrm{pH}$ was adjusted to 5.8. Solutions were placed in glass jars $(3.3 \mathrm{~cm}$ inside diameter and $4.2 \mathrm{~cm}$ in height) and allowed to stand at $25^{\circ} \mathrm{C}$ for 24 $\mathrm{h}$ to allow time for gelation.

\section{Measurement of Gel Strength}

Samples that gelled were cooled at $4^{\circ} \mathrm{C}$ for $24 \mathrm{~h}$ before texture analysis. Gel strength was measured using a Texture Analyzer TA-XT2 (Stable Micro Systems, Godalming, UK). Breaking force was determined by inserting a plastic cylinder probe $(1.3 \mathrm{~cm}$ in diameter) to a depth of $15 \mathrm{~mm}$ into the gel sample at a rate of $1 \mathrm{~mm} /$ s. Measurements were performed in triplicate.

\section{Measurement of Turbidity}

Turbidity was measured at $700 \mathrm{~nm}$ on a Beckman DU 520 UV/Vis Spectrophotometer (Beckman Coulter, Fullerton, CA). A cell with a 1-mm light path was used. Turbidity was measured within $1 \mathrm{~h}$ after sample preparation; measurements were performed in triplicate.

\section{Confocal Scanning Laser Microscopy}

The microstructure of gels was observed by a BioRad MRC 1024 confocal scanning laser microscope (BioRad Laboratories, Hemel Hempstead, UK) according to the method of Lee and Lucey (2004). Only gel samples made with TSPP were analyzed. After addition of TSPP to the MPC solution, acridine orange solution $(2 \mathrm{~g} / \mathrm{L})$ was added at a rate of $1.4 \mathrm{~mL} / 100 \mathrm{~g}$. The sample was then added drop-wise into the concavity of a microscope slide. After covering the milk with a cover glass, the sample was allowed to stand at $25^{\circ} \mathrm{C}$ for gelation. After $24 \mathrm{~h}$, gels were observed by confocal scanning laser microscopy. A $60 \times$ oil immersion objective lens (numerical aperture $=1.4$ ) was used for the observation of gels. After at least 3 fields were observed, typical micrographs were selected.

\section{RESULTS}

\section{Gelation Properties of Different Emulsifying Salts}

Various concentrations of TSC, DSP, TSPP, STPP, or SHMP were added to $51 \mathrm{~g} / \mathrm{L}$ MPC solutions at $\mathrm{pH}$ 5.8 and these solutions were held at $25^{\circ} \mathrm{C}$ for $24 \mathrm{~h}$ and examined to see if they gelled. For TSPP, gelation was only observed at concentrations of 3.8 and $7.6 \mathrm{mM}$ (1 and $2 \mathrm{~g} / \mathrm{L}$, respectively). None of the other types of emulsifying salts gelled under these conditions. To increase the possible chances for gelation to occur we tested the other emulsifying salts under different conditions of temperature and holding time. When $5.5 \mathrm{~m} M(2 \mathrm{~g} / \mathrm{L})$ STPP was added to MPC solutions, gelation was observed after 5,3 , and $2 \mathrm{~d}$ of holding at 25,35 , and $45^{\circ} \mathrm{C}$, respectively. When $3.2 \mathrm{~m} M(2 \mathrm{~g} / \mathrm{L})$ SHMP was added to MPC solutions, gelation was observed after 6 and 5 $\mathrm{d}$ of holding at 35 and $45^{\circ} \mathrm{C}$, respectively. No gelation 


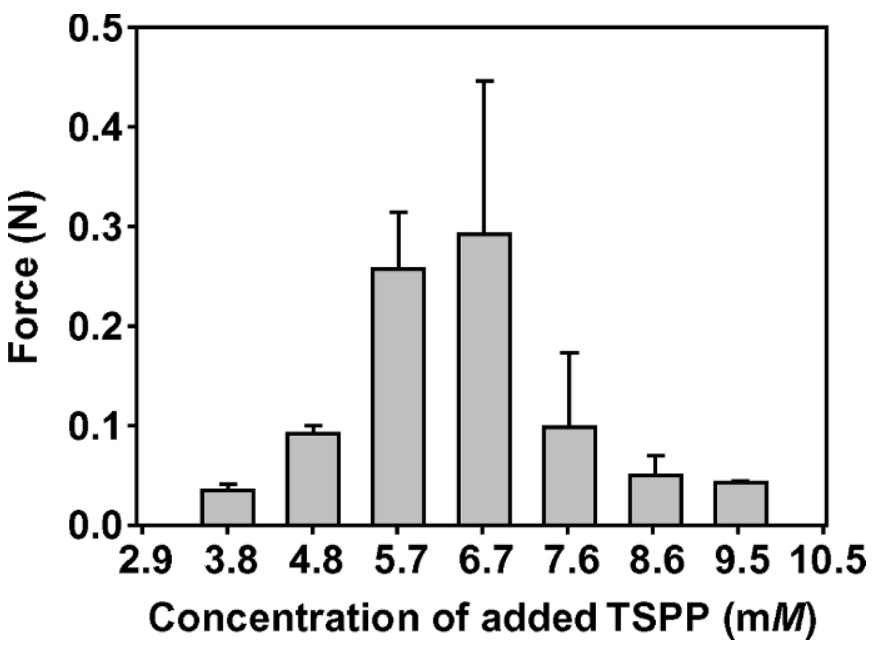

Figure 1. Influence of various concentrations of tetrasodium pyrophosphate (TSPP) on the gel strength of $51 \mathrm{~g} / \mathrm{L}$ milk protein concentrate solutions at $\mathrm{pH}$ 5.8. Results are the mean of triplicates with bars for $95 \%$ confidence intervals.

was observed when $\leq 50.0 \mathrm{mM}(7 \mathrm{~g} / \mathrm{L}) \mathrm{DSP}$ was added to MPC solutions even after $7 \mathrm{~d}$ at $25^{\circ} \mathrm{C}$ (higher temperatures were not tested). However, when the concentration of DSP was increased to $142.9 \mathrm{mM}(20 \mathrm{~g} / \mathrm{L})$, gelation was observed after holding at $25^{\circ} \mathrm{C}$ for $7 \mathrm{~d}$. In contrast, no gelation was observed for TSC under any of the conditions tested.

\section{Influence of TSPP Concentration on Gelation}

The gelation properties of TSPP were investigated further. Tetrasodium pyrophosphate was added to 51 $\mathrm{g} / \mathrm{L}$ MPC solution in increments of $0.95 \mathrm{~m} M$ from 1.9 to $11.5 \mathrm{mM}$. Gelation properties were examined at $\mathrm{pH}$ 5.8 after holding samples at $25^{\circ} \mathrm{C}$ for $24 \mathrm{~h}$ before cooling to $4^{\circ} \mathrm{C}$ and holding for $24 \mathrm{~h}$. Gel strength was measured by a Texture Analyzer (Figure 1). The highest value for the breaking force of gels was observed at $6.7 \mathrm{mM}$ TSPP; no gel was formed when TSPP concentrations of $\leq 2.9$ $\mathrm{m} M$ or $\geq 10.5 \mathrm{~m} M$ were used.

\section{Influence of $\mathrm{pH}$ on Casein Dispersion and Gelation by TSPP}

The influence of $\mathrm{pH}$ on casein dispersion was assessed by measuring the turbidity of MPC solution (Figure 2). The $\mathrm{pH}$ of $51 \mathrm{~g} / \mathrm{L} \mathrm{MPC}$ solution containing $7.6 \mathrm{mM}$ TSPP was adjusted to 5.4 to 7.0 , and turbidity was measured using a spectrophotometer. At high $\mathrm{pH}$ values, turbidity decreased and dispersion of casein was observed. Turbidity increased with a decrease in $\mathrm{pH}$ indicating less casein dispersion. The influence of $\mathrm{pH}$ on gel strength was determined using these MPC solutions. Gelation

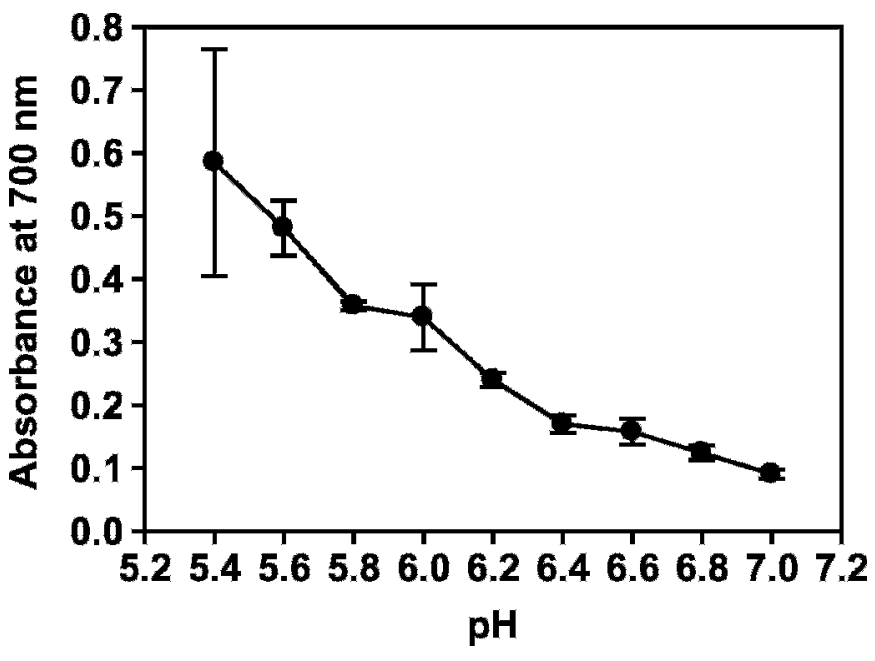

Figure 2. Influence of $\mathrm{pH}$ on the turbidity of $51 \mathrm{~g} / \mathrm{L}$ milk protein concentrate solutions with $7.6 \mathrm{~m} M$ tetrasodium pyrophosphate added. Results are the mean of triplicates with bars for 95\% confidence intervals.

occurred at all $\mathrm{pH}$ values from 5.4 to 7.0 , but the gel strength was highest at pH 6.0 (Figure 3).

\section{Influence of the Addition of $\mathrm{NaCl}$ and $\mathrm{CaCl}_{2}$ on TSPP-Induced Gels}

The influence of the concentration of $\mathrm{NaCl}$ ( 0 to 85.5 $\mathrm{m} M$ ) on TSPP-induced gelation of MPC solution was investigated. Sodium chloride was added to $51 \mathrm{~g} / \mathrm{L} \mathrm{MPC}$ solutions that had $7.6 \mathrm{~m} M$ TSPP and the $\mathrm{pH}$ was ad-

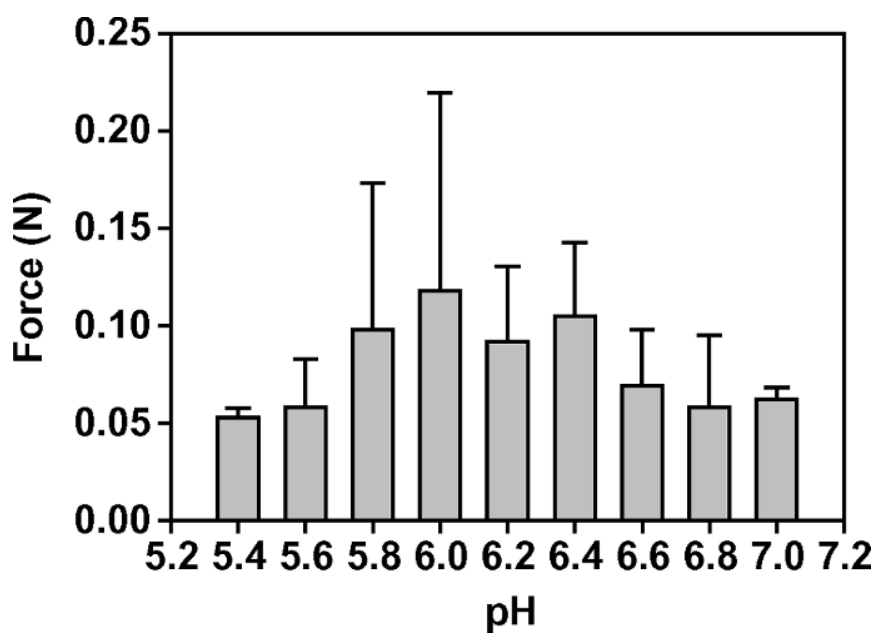

Figure 3. Influence of $\mathrm{pH}$ on gel strength (force, N) of $51 \mathrm{~g} / \mathrm{L}$ milk protein concentrate solutions with $7.6 \mathrm{~m} M$ tetrasodium pyrophosphate added. Results are the mean of triplicates with bars for $95 \%$ confidence intervals. 


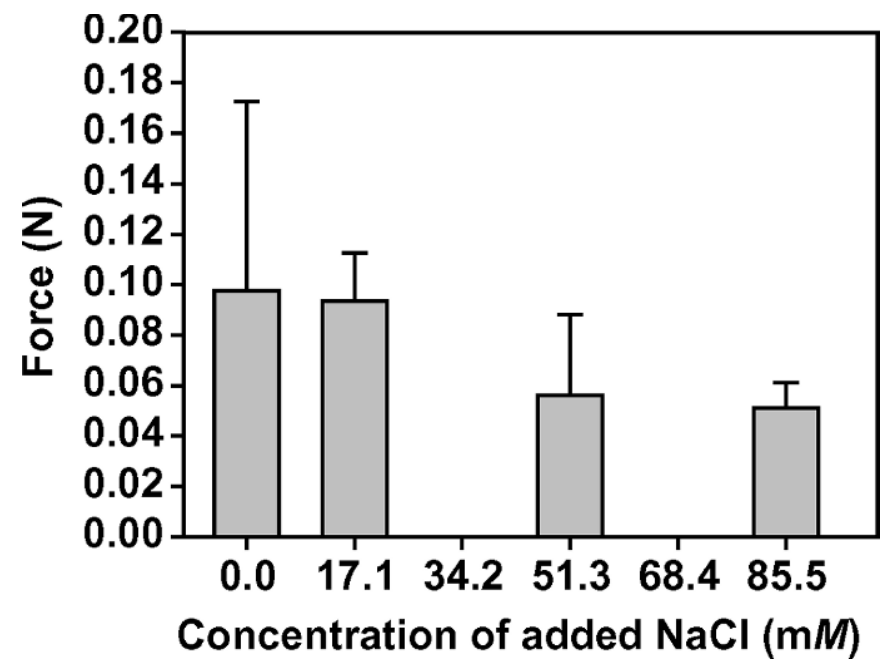

Figure 4. Influence of various concentrations of $\mathrm{NaCl}$ on the gel strength (force, $\mathrm{N}$ ) of $51 \mathrm{~g} / \mathrm{L}$ milk protein concentrate solutions that had $7.6 \mathrm{~m} M$ tetrasodium pyrophosphate added. Results are the mean of triplicates with error bars for standard deviations.

justed to 5.8; gel properties are shown in Figure 4. When $\mathrm{NaCl}$ was added at a concentration of $17.1 \mathrm{mM}$, gelation occurred, and the breaking strength of the gel was similar to that of the $\mathrm{NaCl}$-free control gel. However, as the concentration of $\mathrm{NaCl}$ increased, the breaking force of the gel decreased. When $\mathrm{NaCl}$ was added at a concentration of $85.5 \mathrm{mM}$, the breaking force of the gel was only $\sim 52 \%$ of that of the NaCl-free control gel. The influence of the addition of $\mathrm{CaCl}_{2}$ on gels was investigated. Gelation occurred when the concentration of $\mathrm{Ca}$ was $33 \mathrm{mM}$, but the breaking strength of the gel was similar to that of the $\mathrm{CaCl}_{2}$-free control gel. However, when the $\mathrm{CaCl}_{2}$ concentration was increased to 67 or $100 \mathrm{~m} M$, precipitation, not gelation, occurred.

\section{Influence of Protein Concentration on the Formation of TSPP-Induced Gels}

The influence of increasing the concentration of MPC to $103 \mathrm{~g} / \mathrm{L}$ on the breaking force of gel is shown in Figure 5 . With an increase in the concentration of MPC, the value of the breaking force greatly increased. It was also observed that the TSPP concentration that gave the firmest gels increased from 6.7 to $9.7 \mathrm{mM}$.

\section{Microstructure of TSPP-Induced Gels}

When the gels formed by adding TSPP to $51 \mathrm{~g} / \mathrm{L} \mathrm{MPC}$ solution at concentrations of $3.8,5.7$, or $7.6 \mathrm{~m} M$ were observed by confocal scanning laser microscopy, individual gel particles could not be clearly observed because they were very small, irrespective of the concen-

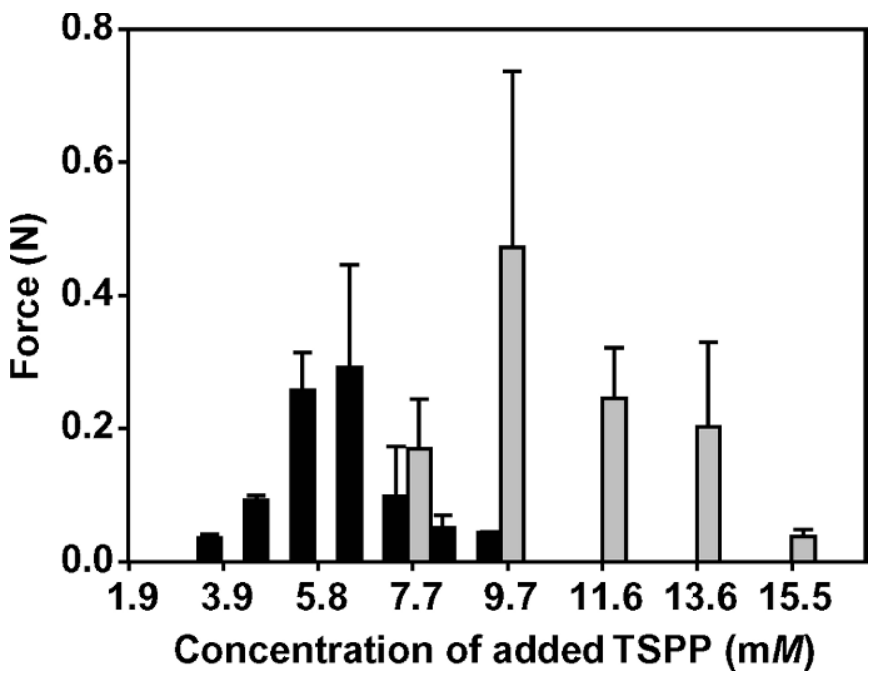

Figure 5. Influence of protein content in milk protein concentrate solutions on the gel strength (force, N). Black bars and gray bars indicate 51 and $103 \mathrm{~g} / \mathrm{L}$ milk protein concentrate solution, respectively. Results are the mean of triplicates with bars for $95 \%$ confidence intervals. TSPP $=$ tetrasodium pyrophosphate.

tration of TSPP (Figure 6a,b,c). However, in gels made with $103 \mathrm{~g} / \mathrm{L}$ MPC solution, larger protein cluster particles could be observed (Figure 6d,e,f). These micrographs indicated that the size of gel-forming particles increased with an increase in the concentration of TSPP (Figure 6d-f).

\section{DISCUSSION}

Tetrasodium pyrophosphate was able to induce milk gelation at room temperature within $24 \mathrm{~h}$ of storage. There have been several previous reports on the formation of puddings or gels from cold milk by the use of pregelatinized starch (to increase viscosity) and a combination of phosphates including TSPP (Clausi, 1957; Breivik et al., 1966). A soluble calcium salt was often added in these preparations as an "accelerator" of gelation (Clausi, 1957). It has also been mentioned (Clausi, 1957) that TSPP alone will cause milk gelation; however, it was noted that the gelation process was very slow (taking several hours). However, these reports do not explain the possible mechanism for this TSPP-induced gelation or describe the detailed gelation properties of these TSPP-induced milk gels.

Recently, there have been several studies investigating how individual emulsifying salts interact with caseins (e.g., Mizuno and Lucey, 2005). When TSPP was added to MPC solutions at pH 5.8, caseins were dispersed and a casein-calcium pyrophosphate complex was formed (Mizuno and Lucey, 2005).

The results of our experiments on the TSPP-induced gelation of MPC solutions indicated that gelation was 

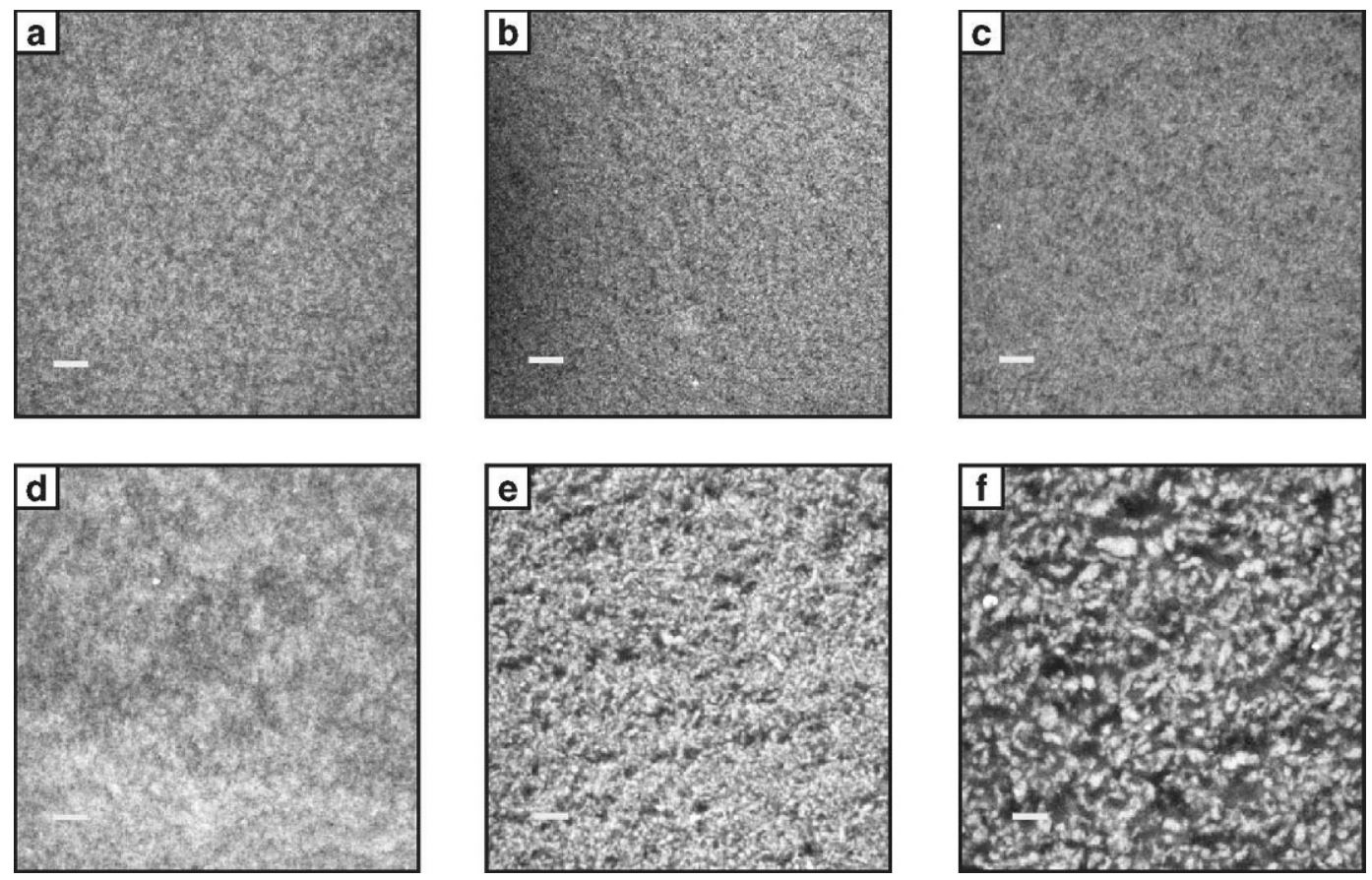

Figure 6. Microstructure of gels of milk protein concentrate solutions with tetrasodium pyrophosphate (TSPP): $51 \mathrm{~g} / \mathrm{L}$ milk protein concentrate $+3.8 \mathrm{~m} M$ TSPP (a), $51 \mathrm{~g} / \mathrm{L}$ milk protein concentrate $+5.7 \mathrm{~m} M$ TSPP $(\mathrm{b}), 51 \mathrm{~g} / \mathrm{L}$ milk protein concentrate $+7.6 \mathrm{~m} M$ TSPP $(\mathrm{c})$, $103 \mathrm{~g} / \mathrm{L}$ milk protein concentrate $+7.7 \mathrm{~m} M$ TSPP (d), $103 \mathrm{~g} / \mathrm{L}$ milk protein concentrate $+9.7 \mathrm{~m} M$ TSPP (e), and $103 \mathrm{~g} / \mathrm{L}$ milk protein concentrate $+11.6 \mathrm{~m} M$ TSPP $(\mathrm{f})$. Scale bar $=20 \mu \mathrm{m}$

influenced by various conditions including $\mathrm{pH}$, ionic strength and emulsifying salts concentration. Aggregation of proteins is governed by a balance between attractive and repulsive forces. Attractive forces in caseins can involve hydrogen bonds, calcium phosphate crosslinks, +/- (plus/minus) charge interactions, and hydrophobic associations, whereas repulsive forces can involve electrostatic interactions, which are affected by the net charge of caseins or the ionic strength of the solution. Gelation occurs when aggregation produces a well-ordered structure; otherwise, precipitation may result.

The addition of TSPP to MPC solutions resulted in the dispersion of caseins (Figure 2) and the formation of casein-calcium pyrophosphate complexes (Mizuno and Lucey, 2005). Dispersion of casein was probably due to the loss of calcium phosphate crosslinks, which are one of the main forces responsible for the formation and stability of casein micelles. Calcium phosphate immobilizes the flexible hydrophilic parts of caseins and imparts a more rigid structure to casein micelles (Rollema and Brinkhuis, 1989). Horne (1998) suggested that calcium phosphate crosslinks were 1 of the 2 main bonding mechanisms responsible for polymerizing individual caseins into the large aggregate that is called the casein micelle. The loss of these crosslinks by the use of TSPP helps to disperse caseins because the abil- ity to maintain these extended polymer chains is lost. The other major bonding mechanism is hydrophobic interaction and some dispersed caseins could still associate via this mechanism. The loss of calcium phosphate may also expose charged phosphoserine groups, thereby increasing electrostatic repulsion between caseins ( $\mathrm{Lu}-$ cey et al., 2003).

A possible mechanism for TSPP-induced gelation of caseins is shown in Figure 7. The first step is the dispersion of caseins. We view this as being analogous to the unfolding of globular proteins that is a prerequisite to thermally induced gelation. Dispersed caseins may not necessarily aggregate and form gels; examples of dispersed caseins that do not form a gel are the caseins that are dispersed by TSC. Phosphate-based emulsifying salts differ from TSC (which forms soluble Ca citrate complexes) in being able to associate with the dispersed caseins (Mizuno and Lucey, 2005). The association of calcium pyrophosphate complexes with dispersed caseins could have 2 important effects. First, binding of these complexes could reduce charge repulsion, which could help facilitate hydrophobic interactions between hydrophobic segments of caseins. Second, there could be some type of specific crosslinking of caseins via calcium pyrophosphates complexes. The primary driving force for this aggregation is likely to be hydrophobic interactions between dispersed caseins. There was a reduction 

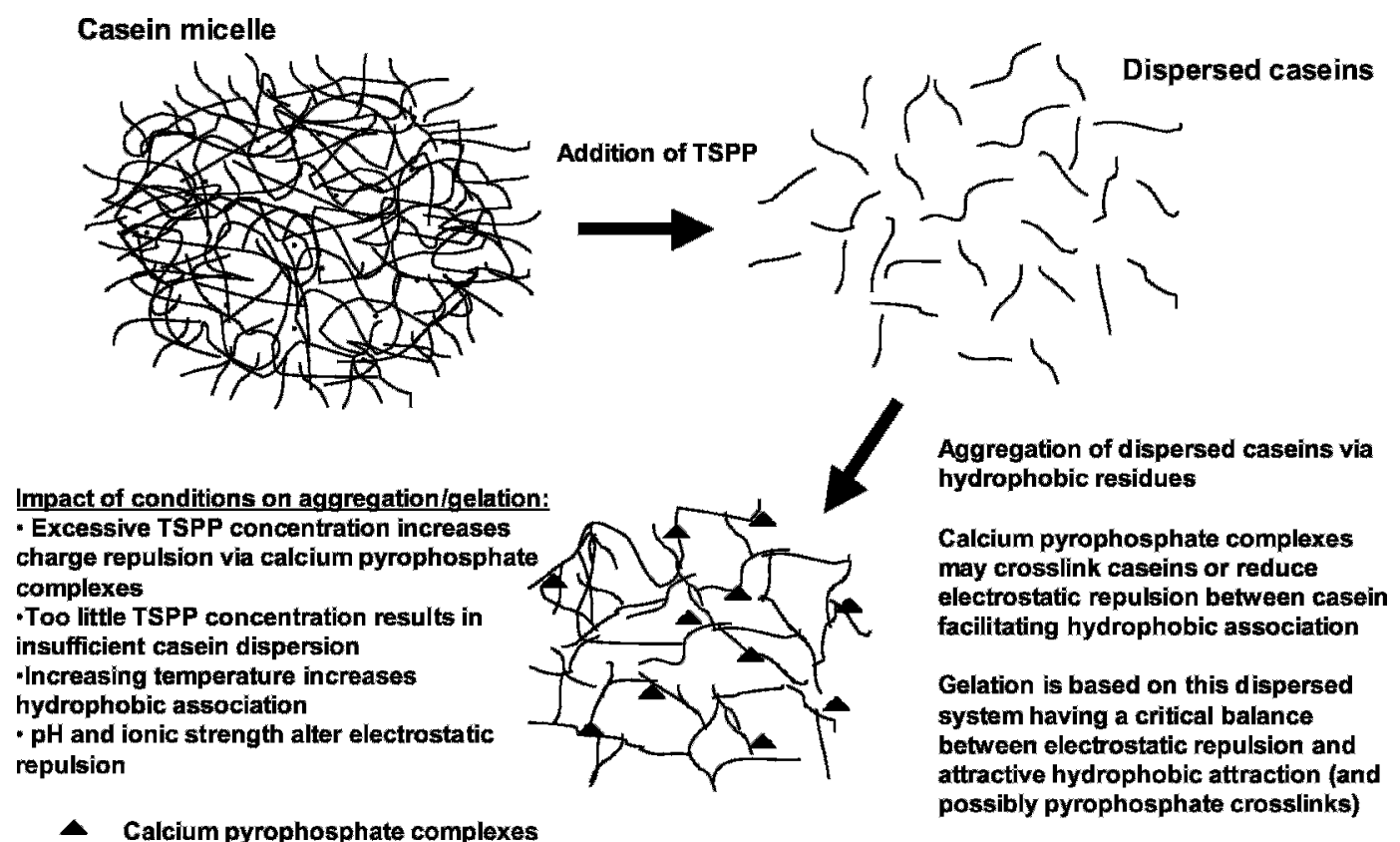

TSPP-induced milk gel

Figure 7. Possible gelation scheme for the formation of tetrasodium pyrophosphate (TSPP)-induced gels from milk protein concentrate solutions.

in gelation time with an increase in temperature for SHMP- and STPP-treated samples, which is consistent with hydrophobic associations of caseins being involved. Electrostatic interactions also play a role as can be seen by the effect of $\mathrm{pH}$ and the addition of $\mathrm{NaCl}$.

Gelation did not occur if very low concentrations $(\leq 2.9$ $\mathrm{m} M$ ) of TSPP were added to MPC solutions (Figure 1). This was probably due to insufficient dispersion of caseins with these low levels of TSPP. On the other hand, when very high concentrations $(\geq 10.5 \mathrm{mM})$ of TSPP were used, casein dispersion occurred but gelation was not observed. Possibly, the high concentration of calcium pyrophosphate complexes associated with dispersed caseins introduced charge repulsion between caseins, inhibiting aggregation. It is also possible that excessive TSPP chelated too much of the available $\mathrm{Ca}$, making it unavailable for crosslinking casein molecules or neutralizing charged groups. The addition of $6.7 \mathrm{mM}$ TSPP to $51 \mathrm{~g} / \mathrm{L}$ MPC solutions resulted in gels with the greatest breaking strength; the turbidity of these MPC solutions was $\sim 0.4$ at $\mathrm{pH} 5.8$ (the turbidity of TSPPfree control solutions was $\sim 0.7$ at $\mathrm{pH} 5.8$ ). These results support the suggestion that at least partial dispersion of casein particles may be necessary for gelation. The addition of SHMP to MPC solutions resulted in similar turbidity values compared with the same corresponding concentrations of TSPP. However, gelation progressed more slowly after the addition of SHMP. One possible explanation is that TSPP is better able to bridge or crosslink casein molecules than other phosphate-based emulsifying salts. In addition, polyphosphates introduce more charge repulsion to caseins due to their multiple negative charges (i.e., polyelectrolyte nature) making it difficult to have reassociation of casein molecules through their hydrophobic segments.

Gelation was also influenced by $\mathrm{pH}$. At lower $\mathrm{pH}$ $(<6.0)$, more and more of the calcium phosphate crosslinks would be dissolved in the MPC solutions. Bonds keeping casein micelles together are weakest or fewest at pH 5.2 or 5.3 (Walstra, 1990). At very high pH (>6.0), calcium phosphate crosslinks are mostly intact but there is an increase in charge repulsion between caseins, which would weaken intermolecular binding between protein molecules (and inhibit aggregation and gelation). However, at very low $\mathrm{pH}(<5.4)$, acid-induced gelation may occur as the system becomes closer to the isoelectric point of casein. At very low $\mathrm{pH}$ values, the indigenous calcium phosphate and probably calcium pyrophosphates complexes from TSPP might dissolve.

The importance of electrostatic interactions in casein aggregation is also clear from the effect of the addition of $\mathrm{NaCl}$. There was a decrease in gel strength of TSPPtreated samples with an increase in $\mathrm{NaCl}$ concentration (Figure 4). It was reported that little or no effect of ionic strength (i.e., $\mathrm{NaCl}$ concentration) was observed on the $\zeta$-potential of casein micelles (Dalgleish, 1984). This 
decrease in gel strength was probably due to the screening of charges on caseins, which reduced the $+/$ - charge (attractive) interactions between dispersed caseins.

Experiments were performed in which $\mathrm{Ca}$ was added to this TSPP mixture to investigate the possibility of $\mathrm{Ca}$ promoting interactions between casein molecules and resulting in an increase in the strength of gel. However, the strength of gels was not increased by the addition of calcium; rather a precipitate was formed at greater concentrations $(\geq 67 \mathrm{mM})$. This suggests that excessive calcium levels considerably decrease the $\zeta$-potential of casein micelles (Dalgleish, 1984) and decrease the electrostatic repulsion between casein particles by binding to negative charges on the casein surface. Excessive aggregation could result in precipitation. Freund and Danes (1960) found that a strong gel was formed when the concentrations of $\mathrm{CaCl}_{2}$, DSP, and TSPP were controlled in a system of milk protein solutions derived from sodium caseinate. It is possible that the addition of calcium could have helped to produce firmer gels under different experimental conditions (e.g., other concentrations of calcium added or other $\mathrm{pH}$ values).

Firmer gels were formed by increasing the concentration of MPC from 51 to $103 \mathrm{~g} / \mathrm{L}$ (Figure 5). As shown in the confocal scanning laser micrographs, larger aggregated protein clusters and pores were visible in gels made with greater protein concentration (i.e., $103 \mathrm{~g} /$ L MPC solutions; Figure 6d,e,f). A fine-stranded gel network was observed (Figure 6e) in the gel with highest gel strength. When greater TSPP concentrations $(>9.5 \mathrm{mM})$ were added to $103 \mathrm{~g} / \mathrm{L}$ MPC solutions, protein clusters were dense and less interconnected and pores were more clearly visible. This could support the suggestion that greater concentrations of TSPP cause an increase in charge repulsion between caseins.

Several phosphate-based emulsifying salts were able to form milk gels at room temperature $\left(\sim 25^{\circ} \mathrm{C}\right)$ although gelation was slow, especially for STPP and SHMP. Very high concentrations of DSP $(142.9 \mathrm{~m} M)$ were needed to induce gelation; even then, gelation took $7 \mathrm{~d}$. It has been reported previously that DSP was much less efficient at causing casein dispersion than SHMP or TSPP when added at a similar weight concentration (Mizuno and Lucey, 2005). Although sodium phosphates other than TSPP were able to induce gelation, their effects were weaker than that of TSPP. When comparing the various types of phosphates, the orthophosphates (e.g., DSP) are relatively poor at complexing $\mathrm{Ca}$. Comparing the ability to complex $\mathrm{Ca}$, phosphates and citrates can be ranked in the following order: long-chain phosphates $>$ tripolyphosphate $>$ pyrophosphate $>$ citrate $>$ orthophosphate (Van Wazer and Callis, 1958). The highly charged anionic nature of polyphosphates causes them to be attracted to, and to orient themselves along, the charged sites of other long-chain polyelectrolytes such as proteins (Van Wazer and Callis, 1958). This should increase the charge repulsion between caseins at $\mathrm{pH}$ values above their isoelectric point (as in the current experiment). At $\mathrm{pH}$ values below the isoelectric point, polyphosphates can induce protein precipitation by cation-anion interactions (Van Wazer and Callis, 1958). In previous studies, casein has been reported to precipitate or aggregate in the presence of phosphates (Lauck and Tucker, 1962; Fox et al., 1965; Zittle, 1966; Guo et al., 2003). The results of these studies indicate either that negatively charged phosphate ions bind to positively charged casein residues (Zittle, 1966) or that phosphate may bind at sites in the interior of casein micelles; for example, carboxyl or phosphoseryl groups (Fox et al., 1965). Panouillé et al. (2003) observed that heat-induced aggregation and gelation of casein micelles could occur in the presence of sodium polyphosphates (those authors did not describe the exact types or amounts of the phosphates in their system) and that this aggregation was dependent on the concentration of casein and $\mathrm{pH}$.

No gels were formed with the use of TSC. Trisodium citrate chelates calcium that is bound to casein, which disrupts the casein micelles, but calcium citrates do not bind to casein and exist as stable, soluble complexes in solution (Mizuno and Lucey, 2005). Citrate cannot act as a cross-linking agent between casein molecules and is not able to induce gelation. In addition, the loss of calcium phosphate crosslinks exposes charged phosphoserine residues and increases charge repulsion between caseins, which inhibits casein aggregation. Citrate is known to inhibit the formation of insoluble calcium phosphate complexes, whereas pyrophosphate enhances their formation (Termine and Posner, 1970). The stability constant (which indicates the relative efficiency of sequestrants) of citrate (3.5) with $\mathrm{Ca}^{2+}$ is lower than pyrophosphate (5.0; Furia, 1972). Hexametaphosphate, tripolyphosphate, and pyrophosphate form much more stable calcium complexes than do orthophosphates (Gosselin and Coghlan, 1953). It is likely that these condensed phosphates could have formed complexes with the dispersed caseins (involving $\mathrm{Ca}$ ) reducing the electrostatic repulsion between casein molecules.

It has been reported that the melting of processed cheese markedly decreases with the use of certain concentrations of TSPP added as an emulsifying salt in processed cheese (Shirashoji et al., 2005). The results of the present study are in agreement with those of Shirashoji et al. (2005), and suggest that part of the gelation mechanism could be due to TSPP-induced 
bridging between casein molecules; in processed cheese, this could result in decreased meltability.

\section{CONCLUSIONS}

Gels could be formed by the addition of TSPP and other phosphate-based emulsifying salts to milk solutions. Gelation was slow when performed at room temperature. Gel properties were dependent on the concentration and type of emulsifying salts, gelation temperature, $\mathrm{pH}$, and the concentration of casein. Sodium hexametaphosphate, STPP, and DSP needed very long times (several days) or high temperatures to produce gels. A mechanism was proposed for the TSPP-induced gelation process that involved the dispersion of the caseins and the slow association of these dispersed caseins via hydrophobic and electrostatic interactions. Similar types of interactions might occur between casein and emulsifying salts during the manufacture of processed cheese. The results of the present study provide fundamental information on the interactions between emulsifying salts and caseins that could be useful for the control of the textural and functional properties of processed cheese.

\section{ACKNOWLEDGMENTS}

The authors appreciate the financial support by Morinaga Milk Industry Co. Ltd. (Kanagawa, Japan). The authors are grateful for the financial support of this research by the Wisconsin Center for Dairy Research (Madison, WI) and Dairy Management Inc. (Rosemont, IL).

\section{REFERENCES}

Berger, W., H. Klostermeyer, K. Merkenich, and G. Uhlman. 1998 Processed Cheese Manufacture, A JOHA Guide. BK Giulini Chemie GmbH \& Co. OHG, Ladenburg, Germany.

Breivik, O. N., W. Slupatcluck, R. J. Carbonell, and G. Weiss. 1966. Instant pudding composition containing an acetylated monoglyceride of a higher fatty acid. Standard Brands Incorporated, assignee. US Patent $3,231,391$.

Clausi, A. S. 1957. Pudding composition and process of producing the same. General Foods Corporation assignee. US Patent 2,801,924.

Dairy Management Inc. (DMI). 2004. Innovations in dairy: Controlling processed cheese functionality. Technical Bulletins. DMI, Inc., Rosemont, IL. http://www.innovatewithdairy.com/Innovate-
WithDairy/Articles/TB_Home_032905.htm Accessed May 16, 2007.

Dalgleish, D. G. 1984. Measurement of electrophoretic mobilities and zeta-potentials of particles from milk using laser Doppler electrophoresis. J. Dairy Res. 51:425-438.

Fox, K. K., M. K. Harper, V. H. Holsinger, and M. J. Pallansch. 1965. Gelation of milk solids by orthophosphate. J. Dairy Sci. 48:179-185.

Fox, P. F., T. P. Guinee, T. M. Cogan, and P. L. H. McSweeney. 2000. Fundamentals of Cheese Science. Aspen Publishers Inc., Gaithersburg, MD

Freund, E. H., and E. N. Danes. 1960. Method of improving the properties of meat and composition therefor. National Dairy Products Corporation, assignee. US Pat. No. 2,957,770.

Furia, T. 1972. Sequestrants in food. Pages 271-294 in Handbook of Food Additives. 2nd ed. T. E. Furia, ed. CRC Press, Cleveland, OH.

Gosselin, R. E., and E. R. Coghlan. 1953. The stability of complexes between calcium and orthophosphate, polymeric phosphate, and phytate. Arch. Biochem. Biophys. 45:301-311.

Guo, C., B. E. Campbell, K. Chen, A. M. Lenhoff, and O. D. Velev. 2003. Casein precipitation equilibria in the presence of calcium ions and phosphates. Colloids Surf. B Biointerfaces 29:297-307.

Gupta, S. K., C. Karahadian, and R. C. Lindsay. 1984. Effect of emulsifier salts on textural and flavor properties of processed cheeses. J. Dairy Sci. 67:764-778.

Horne, D. S. 1998. Casein interactions: Casting light on the black boxes, the structure in dairy products. Int. Dairy J. 8:171-177.

Lauck, R. M., and J. W. Tucker. 1962. Functional properties of calcium and protein in nonfat dry milk used in food products. Cereal Sci. Today 7:314-322.

Lee, W.-J., and J. A. Lucey. 2004. Rheological properties, whey separation, and microstructure in set-style yogurt: Effects of heating temperature and incubation temperature. J. Texture Stud. 34:515-536.

Lucey, J. A., M. E. Johnson, and D. S. Horne. 2003. Perspectives on the basis of the rheology and texture properties of cheese. J. Dairy Sci. 86:2725-2743.

Mizuno, R., and J. A. Lucey. 2005. Effects of emulsifying salts on the turbidity and calcium-phosphate-protein interactions in casein micelles. J. Dairy Sci. 88:3070-3078.

Odagiri, S., and T. A. Nickerson. 1964. Chain length determination of polyphosphate. J. Dairy Sci. 47:920-921.

Panouillé, M., T. Nicolai, and D. Durand. 2003. Heat induced aggregation and gelation of casein submicelles. Int. Dairy J. 14:297-303.

Rollema, H. S., and J. A. Brinkhuis. 1989. A ${ }^{1} \mathrm{H}-\mathrm{NMR}$ study of bovine casein micelles; influence of $\mathrm{pH}$, temperature and calcium ions on micellar structure. J. Dairy Res. 56:417-425.

Shirashoji, N., J. J. Jaeggi, and J. A. Lucey. 2005. Effects of various emulsifying salts on the rheological and textural properties of pasteurized process Cheddar cheese. J. Dairy Sci. 88(Suppl. 1):19. (Abstr.)

Termine, J. D., and A. S. Posner. 1970. Calcium phosphate formation in vitro. 1. Factors affecting initial phase separation. Arch. Biochem. Biophys. 140:307-317.

Van Wazer, J. R., and C. F. Callis. 1958. Metal complexing by phosphates. Chem. Rev. 58:1011-1046.

Walstra, P. 1990. On the stability of casein micelles. J. Dairy Sci. 73:1965-1979.

Zittle, C. A. 1966. Precipitation of casein from acidic solutions by divalent anions. J. Dairy Sci. 49:361-364. 